\title{
The L2 acquisition of a phonological variable: the case of $/ 1 /$ deletion in French
}

\author{
MARTIN HOWARD ${ }^{1}$ \\ University College, Cork \\ ISABELLE LEMÉE \\ Dublin City University \\ VERA REGAN \\ University College, Dublin
}

(Received February 2005; revised October 2005)

\section{A B S T RAC T}

This article is situated within the recent strand of SLA research which applies variationist sociolinguistic methods to the study of the acquisition of sociolinguistic variation by the L2 speaker. Whilst that research has tended to focus on the study of morphological and morphosyntactic variables, this article aims to investigate a number of acquisitional trends identified in previous research in relation to phonological variation, namely the variable deletion of /1/ by Irish advanced L2 speakers of French in both an instructed and study abroad environment. Based on quantitative results using GoldVarb 200 I, the study further illuminates the difficulty that the acquisition of sociolinguistic variation poses to the instructed L2 speaker, who is found to make minimal use of informal sociolinguistic variants. In contrast, contact with native speakers in the native speech community is seen to allow the L2 speaker to make considerable sociolinguistic gains, not only in relation to the acquisition of the informal variant in itself, but also in relation to the underlying native speaker grammatical system as indicated by the constraint ordering at work behind use of the variable.

\section{IN T RODUCTION}

In second language (L2) acquisition research, there has been a recent proliferation of studies which expand and develop the area of sociolinguistic competence. Variationist sociolinguistics in the past 20 years or so has brought its theoretical and methodological apparatus to bear on L2 research, as described, for example, by Bayley and Preston (I996), Bayley and Regan (2004), Preston (1989) and Young (I99I). One thread in the recent past has focused particularly on the acquisition of native speaker variation patterns (see, for example, Adamson and Regan, I99i;

${ }^{1}$ Funding to the first author is gratefully acknowledged while pursuing research for this paper as an IRCHSS Government of Ireland Research Fellow. 
Howard, 2004, 2005a; Lemée, 2003; Major, 2004; Mougeon et al., 2002; and Regan, I996). This research focuses on the way in which L2 speakers make choices in much the same way as native speakers do, depending on their level of proficiency, between the different variants of a particular variable in native speech, such as in the case of the variable deletion of the negative particle 'ne' or the choice between the subject pronouns 'nous'/'on' in French. The choice of variant is constrained by many factors, which are linguistic, social and stylistic in nature. Such variation has been seen to be an inherent characteristic of native speech, and exists at all levels of language: phonological, lexical, morphological, syntactic and discourse. (For an overview of such intrinsic, systematic variation in native speaker speech, see, for instance, Eckert and Rickford, 200 I; Labov, I994, 200I; Trudgill and Cheshire, I998).

\section{VARIATION AND SECOND LANGUAGE SPEECH}

The L2 variability which is part of the acquisition of such variation between two or more native-like forms is in contrast to the variability between a target and non-target form in learner language. Such learner-specific variability has been the focus of much investigation in relation to specific conceptual entities such as the expression of temporality and gender, as well as other aspects of the L2 speaker's general morphological and morpho-syntactic use (in the former case, see, for example, Howard, 2002, 2005b, 2005c; and Dewaele and Véronique, 200I, and in the latter case, see, for example, Dewaele, I995). In contrast to the more traditional focus on the study of such linguistic variability in $\mathrm{L}_{2}$ research, this paper is situated within the more recent wave of studies which aims to illuminate the L2 learner's acquisition of sociolinguistic variation. ${ }^{2}$

With regard to the study of the acquisition of sociolinguistic variation, SLA research has so far tended to focus on L2 French. ${ }^{3}$ Those studies investigate learners in a range of contexts of acquisition, and, as such, allow an interesting comparison to be made of differences and similarities characterising different learner populations. They principally include Mougeon et al.'s study of Canadian classroom learners of French in an immersion setting who receive a significant proportion of their schooling through French, but live in predominantly Anglophone communities; ${ }^{4}$ Blondeau et al.'s study of Canadian adults learning French in a naturalistic milieu in the predominantly Francophone city of Montreal; ${ }^{5}$ the Dutch-speaking university

${ }^{2}$ In their overview of the L2 acquisition of sociolinguistic variation, Mougeon et al. (2002) and Rehner (2004) similarly make a distinction between the two types of variation, referring to learner-specific variability as one type of variation which can be distinguished from a second type concerning the sociolinguistic variation at work in the native speaker's language use. For overview presentations of linguistic variability in L2 acquisition, see Bayley and Preston (I996), Gass et al. (I989), Preston (I989), Towell and Hawkins (I994) and Young (I99I, I999).

3 Important exceptions, however, include Adamson and Regan (I99I), Major (2004) and Olson Flanagan and Inal (1996).

${ }^{4}$ For an overview of such work, see Mougeon et al. (2002) and Rehner et al. (2003).

${ }^{5}$ For an overview of such work, see Blondeau et al. (2002). 


\section{L2 acquisition of a phonological variable}

learners of French investigated by Dewaele in a foreign language classroom environment; ${ }^{6}$ and the Irish study abroad speakers in projects conducted by the individual authors of this paper. ${ }^{7}$ In the latter case, the speakers are university learners of French in the foreign language classroom, but have also experienced naturalistic acquisition in France during a one year 'study abroad' sojourn.

Recent comparative syntheses of such work, such as Bayley and Regan (2004) and Dewaele and Mougeon $(2002$, 2004) point to a number of important overriding trends in research on the $\mathrm{L}_{2}$ acquisition of sociolinguistic variation. Whilst sensitivity to such sociolinguistic variation can occur quite early in the acquisition process, in particular, such variation has been observed to emerge later in the acquisition process. Such a general finding raises the question of whether development on the L2 grammatical structure may precede the learner's ability to vary in use between two or more sociolinguistic forms which express the same meaning in context. The late acquisition of sociolinguistic variation is in contrast with that observed in children as young as three years old who are observed to have already acquired such variation patterns. Roberts (I994), for instance, has shown that children of that age acquire community variation patterns for the 'in'/'ing' variable in English. The acquisition of native speaker variables in L2 speech, however, can present greater difficulty. For example, in her study of the variable deletion of the negative particle 'ne' by Irish learners who had been learning French for seven-eight years in a classroom environment, Regan (I995, I996, 2004) finds that deletion is minimal such that some learners categorically produce the formally more complex prestige variant 'ne... pas'.

Even in the case where classroom learners do demonstrate sociolinguistic variation, it has generally been observed that they underuse informal variants in favour of more formal ones, where informal variants are those seen to characterise an informal style in native speech such as the non-realisation of 'ne' or $/ 1 /$ in French, while their formal variants, consisting in the realisation of 'ne' or $/ 1 /$, characterise a formal style. As such, a 'plateau' effect is characteristic of classroom learners, whereby comparisons of their levels of usage of sociolinguistic markers with those of the native speaker reveal considerable differences. For example, in their study of 'ne' deletion, in this case, by Canadian classroom immersion learners of French, Rehner and Mougeon (I999) report an average rate of deletion of 28 per cent. This is in contrast to the quasi-categorical levels demonstrated by the native speaker in a range of francophone communities in Canada, including Québec and other more restricted speech communities in Ontario. ${ }^{8}$ Indeed, in view of such findings concerning the instructed learner's preference for the use of formal markers

6 See, for example, Dewaele (2002a, 2004a).

${ }^{7}$ See, for example, Howard (2004, 2005a), Lemée (2002) and Regan (I996, 2004). For an overview of such work, see Regan, Howard and Lemée (to appear).

${ }^{8}$ Exceptions to this conclusion concern Mougeon and Rehner's (I 999) study of the use of adverbs of restriction, namely 'juste', 'seulement', and 'rien que', where their Canadian immersion learners are seen to approach native speaker norms concerning use of the informal variant 'juste'. 
in many cases, a number of authors point to the limitations of the classroom, in both immersion and foreign language contexts, as a domain facilitating the acquisition of sociolinguistic variation. In particular, Dewaele and Regan (2002), Howard (2004, 2005a), and Lyster (I994) call into question the social boundaries which define the classroom as a domain of social interaction, such that genuine opportunities for use of informal variants may be restricted for both teacher and learner alike. Rehner et al. (2002) further point to the need for the development of pedagogical materials which adequately incorporate such sociolinguistic variation so as to give rise to genuine classroom interaction where such variation is exemplified in an immersion context. ${ }^{9}$ Indeed, the highly beneficial effect of a functional-analytical approach to the learning of sociolinguistic variation is reported on by Lyster (I994). Lyster presents an experimental study which compared Canadian learners of French in an immersion classroom where a functional or communicative approach was adopted, and an experimental group of learners whose communicative learning was supplemented with analytical learning of sociolinguistic markers. Findings indicate that those learners in the experimental group made more significant sociolinguistic gains compared to the control group.

Whilst Lyster's study calls for a more innovative approach to the teaching of sociolinguistic competence in a classroom environment, visits to the target language community by the classroom learner have equally been seen to have a positive effect on the acquisition of sociolinguistic competence. For example, Regan (I995, I996) notes that her Irish informants dramatically increased their level of 'ne' deletion during a year in France. Regan (2004) further notes that such a stay in the target language community seems to consolidate the learner's sociolinguistic skills, whereby, up to one year following their return to the foreign language classroom, her learners generally maintained their increased levels of deletion. A similarly important effect for native-speaker contact outside the classroom is reported by the Canadian classroom immersion studies, whereby length of residence with a native-speaker family in Québec is seen to increase the learners' use of informal markers, such as the use of 'on' and restrictive adverbs. ${ }^{10}$ Similarly, Dewaele (I992, 2002) reports an effect for target language contact through reading and media access in his studies of 'ne' deletion and use of 'nous' /'on' by Flemish university learners of French.

The findings of those studies investigating classroom learners point to the highly beneficial effect of native-speaker contact on sociolinguistic development. Nonetheless, they equally find that the learners' level of use of informal markers falls short of that observed in the native speaker. As such, a certain limitation appears to characterise the classroom learner's capacity to acquire such similar levels of usage even during a period of residence in the target language community. This is in contrast with the general findings in the case of wholly naturalistic

9 This is in spite of the fact that the development of the immersion learner's sociolinguistic competence is identified as a goal within the French language education curriculum.

${ }^{10}$ For the respective studies, see Rehner et al. (2003) and Mougeon and Rehner (200I). 


\section{L2 acquisition of a phonological variable}

learners residing in the target language community. For example, across a range of variables, Blondeau et al. (2002) report levels of use of the informal variants which very closely approach native speaker norms. In particular, they report an effect for 'social integration', whereby those learners who demonstrated the greatest social integration most closely assumed native speaker norms, such that differences with native speakers in their levels of usage of informal variants were found to be minimal. Indeed, the important effect found in Blondeau et al.'s work for social integration further points to the limitations of the classroom environment by calling into question the extent to which real 'social integration' can evolve in such a context. If it cannot, and in view of the more limited sociolinguistic development which previous studies document, it may simply be the case that 'social integration' is the missing factor in the classroom environment, giving rise to the 'plateau effect' previously alluded to. It must be acknowledged, however, that the special bilingual language contact situation in which Blondeau et al.'s learners found themselves in Montréal may have an added impact in their study. That factor may be an important issue that differentiates the authors' findings from those presented by Adamson and Regan (I99I). In the latter case, although also dealing with naturalistic learners, in this case of Cambodian and Vietnamese origin in the US, the authors find that the learners do not attain the same levels of usage of the variable under investigation, namely the variable realisation of /ng/ and /n/ in L2 English. In view of such a discrepancy in findings, an interesting issue which remains to be more amply investigated concerns how community membership might play a crucial role in sociolinguistic development.

Whilst a more limited effect emerges for classroom instruction in relation to the learner's level of use of informal variants, variation studies of the acquisition of native speaker variation patterns are also concerned to analyse the constraint ordering of factors which affect choice of variant. Factors are both linguistic and social, such as the characteristics of the grammatical and phonetic context in which the variable occurs, as well as the speaker's age, gender, social class, and speech style. In sociolinguistic research, such factors are seen to consist in different constraints, such as male and female in the case of the effect of the speaker's gender, or different agegroups in the case of the factor of age. In relation to the native speaker, a wide range of studies over many years since Labov's pioneering work in the I960s shows that variation is systematic and not random as had been previously supposed, whereby a range of contextual factors systematically favour use of a particular variant, and, in so doing, disfavour use of the alternative variant. Many quantitative studies of such variation have thrown up interesting detail on native speaker constraint ordering, and on the progressive acquisition of such ordering by the L 2 speaker. Such studies often provide computational analysis of this variation through the application of the VARBRUL computer program for the purpose of analysing naturalistic speech data. Through multivariate analysis, the VARBRUL program captures in probabilistic terms the relative effect of a range of contextual factors on the speaker's choice of a particular variant, such that a constraint order can be established concerning those constraints which most favour use of a particular variant as opposed to those that 
do so to a relatively lesser extent. In many cases, though not all, ${ }^{11}$ similar constraint orderings are found in non-native speech as in native speech, whereby not only do similar factors influence the L2 speaker's choice of a variant, but the impact of the factors in terms of the relative effect of their constraints may also be similar to that observed in the native speaker, giving rise to a similar constraint ordering. Whether or not the constraint ordering is similar seems to be often due to level of proficiency, whereby comparative L2 studies such as Regan (I995, I996), Mougeon and Rehner (200I), and Uritescu et al. (2004) show that, the greater the proficiency of the L2 speaker, the more the constraint ordering resembles that of the native speaker.

In summary, the conclusions drawn from previous research provide a number of important insights into the acquisition of sociolinguistic variation by the $\mathrm{L} 2$ learner. Those insights principally relate to:

- the relationship between proficiency level and the learner's developmental capacity to acquire a sociolinguistic repertoire;

- the process whereby the L2 speaker acquires use of informal as opposed to formal sociolinguistic markers;

- the relationship between foreign language instruction, exposure to native speaker speech and their effects on the use of informal sociolinguistic markers;

- the learner's use of a sociolinguistic variable and the role of constraint ordering in relation to use of the variable.

Having presented a synopsis of the important conclusions to be drawn from previous studies of the acquisition of sociolinguistic variation, the following section will draw on those conclusions to identify the research questions at play in the study undertaken for the purposes of this article.

\section{BACKGROUND RESEARCH QUESTIONS TO THE STUDY}

Whereas previous research has provided insight into the acquisition of a range of sociolinguistic variables, the issue of the relative difficulty posed by the acquisition of different variables by the classroom learner has been somewhat neglected. In particular, previous studies of L2 French have tended to neglect phonological variables in favour of morphological and morphosyntactic variables such as 'ne' deletion, ${ }^{12}$ the variable use of 'nous'/ 'on', ${ }^{13}$ the variable use of 'tu'/ "vous', ${ }^{14}$ the variable expression of futurity in terms of use of the present, 'aller' + infinitive, and the synthetic future form, ${ }^{15}$ the use of interrogative forms, ${ }^{16}$ and subject doubling. ${ }^{17}$

11 See Adamson and Regan (I99I); Bayley (I996); and Young (I99I).

12 See Dewaele (I992, 2004a); Dewaele and Regan (2002); Regan (I995, I996, 2004) and Rehner and Mougeon (I999).

13 See Dewaele (2002a); Lemée (2002) and Rehner et al. (2003).

14 See Dewaele (2002b, 2004b) and Lyster and Rebuffot (2002).

15 See Nadasdi et al. (2002).

16 See Dewaele (I999).

17 See Nagy et al. (2004). 


\section{L2 acquisition of a phonological variable}

To a lesser extent, lexical variation and variation in discourse have also been investigated, ${ }^{18}$ as well as the use of stigmatised vernacular forms, described by Rehner et al. (2003) as more restricted in use by the native speaker to a particular social group, as opposed to informal variants which are more generally used across social groups.

Such studies of different types of variable allow an important insight into the relative difficulty surrounding their acquisition. For example, findings by Rehner et al. (2003) point to the L2 speaker's non-use of stigmatised vernacular forms. Such findings contrast with the authors' findings for other less stigmatised variable items, where the learners' increased usage of the informal variant goes someway to pointing towards their greater ease of use compared to marked vernacular forms.

In contrast to the categories of variable outlined, phonological variables have been relatively less the focus of attention: although more amply investigated in the case of the naturalistic learner by Blondeau et al. ${ }^{19}$ the study of phonological variables has generally been restricted to Howard (2004, 2005a), Mougeon (200I), Thomas (2002) and Uritescu et al. (2004) in the case of L2 French, and Adamson and Regan (I99I), Bayley (I996) and Major (2004) in the case of L2 English. Findings from Blondeau et al.'s work on phonological variation generally corroborate their findings in the case of other variables. That is to say, in the case of the L2 speakers in their study who demonstrate high levels of social integration, those speakers were found to closely approach similar levels of usage of informal sociolinguistic markers to those of native speakers. Bayley (I996) also finds a similar effect for social integration in his study of $\mathrm{t} / \mathrm{d}$ deletion by naturalistic Chinese learners of English in the US, whereby those learners demonstrating high levels of integration were found to use the informal variant more frequently, so as to delete $t / d$ in examples such as 'I missed dinner'. Adamson and Regan (I99I) also study naturalistic learners of English in the US. In their study of the variable use of $/ \mathrm{ng} /$ and $/ \mathrm{n} /$ as in 'running' as opposed to 'runnin', the authors find an important effect for the speaker's gender on use of the variable, whereby male speakers use the informal variant to a greater extent than female speakers who use more formal variants. This is similar to native speaker gender patterns. In a study which investigates a range of phonological variables in the L2 English of Japanese and Spanish learners in the US, Major (2004) similarly presents findings which show that they acquire similar gender patterns as those characterising native speakers. Style differences were also observed.

In the case of classroom immersion learners, findings in relation to the acquisition of phonological variation patterns are principally restricted to those in a Canadian

18 In the case of L2 French, see Dewaele (2004c, Dewaele and Regan 200I) in relation to the use of slang vocabulary, Mougeon and Rehner (I999) on the use of adverbs of restriction, Nadasdi and McKinnie (2003) on the lexical expression of the concepts of 'living' and 'working', and Sankoff et al. (I997) on the variable use of discourse markers. In the case of L2 English, see Olson-Flanagan and Inal (1996) on use of the relative subordinators 'that', 'which', and 'o'.

19 See Blondeau et al. (2002) as well as Nagy et al. (1996) for a synopsis of findings. 
immersion context reported on by Mougeon et al. (200I) and Uritescu et al. (2004). In the former case, the authors investigate their learners' deletion of /1/ in subject pronouns, namely 'il', 'elle', 'ils' and 'elles'. In contrast with their findings for morphological and morphosyntactic variables, the authors find that the learners' use of the informal phonological variant, that is to say, non-realisation of /1/ is quasi non-existent. In contrast, in the case of the study of schwa deletion by Uritescu et al., the findings indicate closer approximation to native speaker norms. Here, learners demonstrate higher levels of deletion, albeit not to the same extent as the native speaker. The differences in findings for the two variables point to the relative difficulty posed by certain variables within a similar category such as that of phonological variables, and also suggest the need to compare findings for different variables across categories.

In summary, a clear difference emerges between the studies of naturalistic learners and the classroom immersion learners in terms of their level of use of particular variables: the naturalistic learners studied by Blondeau et al. approach native speaker norms in terms of their level of use of a range of different variable types. Similarly, naturalistic L2 learners of English reporting high social integration are equally seen to make frequent use of the informal variants studied by Adamson and Regan and Bayley. In contrast, not only are immersion learners seen to under use a range of informal variants, but even within a particular category of variables such as those of a phonological nature, certain variables pose considerably greater difficulty than others. The question remains as to how such relative difficulty across variables as well as within a particular variable type might equally characterise the instructed learner in the foreign language classroom. On this score, in a study of Canadian university learners, Thomas (2002) presents results which point to considerable overuse of formal variants. In the case of schwa deletion, he writes, '[T] ous contextes confondus, le maintien du schwa est généralement minoritaire en FLI, mais majoritaire en FL2', where FLI refers to native speech, and FL2 to learner language (2002: I09). Similarly, in the case of his findings concerning /1/ deletion in $\mathrm{FL}_{2}$, the author reports 'ils maintiennent la variable de manière très majoritaire, tout à fait à l'opposé du comportement dominant des francophones' (2002: I I4). In a study of the variable realisation of liaison by anglophone instructed learners of French, Howard $(2004,2005$ a) similarly finds significant discrepancies between the L2 speaker and the native speaker which manifest themselves primarily in terms of the much reduced use of liaison by the L2 speaker across a range of syntactic contexts.

As this overview of previous research shows, compared to other types of variation, the study of phonological variation has been somewhat less the focus of attention of sociolinguistic researchers in $\mathrm{L} 2$ acquisition studies. This is particularly true in the case of the instructed learner, where findings are predominantly based on studies of Canadian immersion learners. As such, by drawing on data from learners in a European context for whom a Canadian francophone variety is less likely to be their linguistic benchmark than a continental one, this article attempts to contribute to existing research findings. Bearing in mind Ervin-Tripp's (1972) important notion 


\section{L2 acquisition of a phonological variable}

that sociolinguistic competence cannot be understood in terms of a single variable, but only in terms of the co-occurrence of patterns of use of formal and informal variants, the acquisition of variation in phonology by the L2 speaker is important in order to complete the picture of the acquisition of sociolinguistic variation as a multidimensional construct. The research questions behind the study focus around three central issues:

- What are the characteristics of the acquisition and use of the phonological variable under investigation here by the instructed L2 speaker?

- Does contact with native speakers have a positive effect on the instructed L2 speaker's acquisition of phonological variation and sociolinguistic competence as it seems to have on general language learning (Collentine and Freed, 2004)?

- Given that L2 speaker constraint hierarchies seem at times to match LI constraints in morphology and morphosyntax, is this also the case for the acquisition of the phonological variable under investigation here? Furthermore, in response to Rehner et al.'s (2003: I50) call for 'research that investigates the learning of specific linguistic constraints by FSL learners of similar levels of proficiency and similar levels of Li exposure', our study aims to provide insight into how the instructed learners' acquisition of the constraints at work behind use of a phonological variable compares with their acquisition of such constraints in the case of other variable types.

The issues outlined will be considered in relation to variable /l/ deletion in the target language French.

\section{/1/ DELETION AS A PHONOLOGICAL VARIABLE IN FRENCH}

/1/ deletion has been attested in both continental and Canadian French, as previously studied by Armstrong (I996, 200I), Ashby (I984) and Laks (I980) in France, and Poplack and Walker (I986) and Sankoff and Cedergren (1976) in a Canadian context. These studies exemplify the range of contexts in which /1/ deletion is attested to varying degrees. Those contexts point to the occurrence of this variable in word-initial, word-median and word-final position, namely in third person subject pronouns 'il' with both personal and impersonal values, 'elle', 'ils' and 'elles'; the object pronouns 'le', 'la', 'les', 'lui' and 'leur'; the definite articles 'le', 'la' and 'les'; and in a range of other words such as 'escalier' and 'table'.

A comparison of the native speaker studies suggests that the informal variant, (non-realisation of $/ 1 /$ ), is more frequent in the case of third person pronouns than in other contexts. For example, in their study of Canadian francophone speakers, Poplack and Walker (I986) report rates of deletion ranging from 33 per cent in the case of 'elles' to Ioo per cent in the case of impersonal 'il'. In other words, in the latter case, realisation of $/ 1 /$ is non-existent. Sankoff and Cedergren (I976) report similarly high levels of deletion, reaching 98 per cent in the case of impersonal 'il' in their study of francophone speakers in Montréal. Such levels of deletion are somewhat higher than in the case of Ashby's (I984) study of continental speakers in 
Tours, where rates of deletion occurred within a range of 63 per cent in the case of 'elle', and 88 per cent in the case of impersonal 'il'. Armstrong (1996) offers similar findings in his study of adolescents in Eastern France whose rates of deletion range from Is per cent in the case of 'elle' to near-categorical levels in the case of 'il'. A final study by Laks (I980) in Paris reports similar differential rates of deletion across pronouns which are also lower than in the case of Canadian speakers: rates range from 33 per cent in the case of 'elle' to 94 per cent for impersonal 'il'.

Rates of deletion are found to be lower in other contexts such as object pronouns where rates of deletion range between 0.5-9I per cent in Poplack and Walker's Canadian study and between .04-2I per cent in Ashby's study, and definite articles where rates range between $7-38$ per cent in the Canadian context. ${ }^{20}$ Such variation in the native speaker has also been found to be systematically constrained by an extensive range of phonetic, grammatical, social and stylistic factors. The effect of such factors has been investigated in the case of L2 learner-informants in the present study with a view to considering to what extent they might share a similar system of constraints. These factors are detailed in the presentation of our data analysis below.

In the case of the instructed $\mathrm{L}_{2}$ learner, previous studies of this variable are based on the Canadian immersion learners studied by Mougeon et al. (200I) and the Canadian university learners studied by Thomas (2002). As previously noted above, both studies point to the limited use of the informal variant, particularly in the case of immersion learners who produce the formal variant at near-categorical levels. A further study by Sax (2000) of American instructed L2 speakers produces similar findings. It remains to be seen to what extent this variable might pose greater/lesser difficulty to the L2 instructed learner in a European context in terms of rates of usage, as well as the factors which constrain its use by the native speaker.

\section{THE STUDY}

\section{Speakers}

The study is based on an analysis of the spoken data produced by nineteen speakers, nine male and ten female. Fifteen of our speakers had spent an academic year in France, and four had never gone to France. At the time of the data elicitation, the speakers were final year university students specialising in French as part of their undergraduate degree programme. Aged between I9 and 2I years, the learners had completed three years of French studies at university, one of which was spent at a university in France in the case of our study abroad speakers. The study therefore provides insight into the effect of such naturalistic target language exposure on the instructed learners' acquisition of the variable under investigation. The informants had also previously been learning French for five-six years at school where they also learnt Irish, and in some cases, another foreign language.

${ }^{20}$ Deletion in the case of definite articles was not studied by Ashby. 


\section{L2 acquisition of a phonological variable}

For the purposes of the data elicitation, the learners participated in individual sociolinguistic interviews conducted in French by one of the authors. The interviews yielded 2,2 I 4 tokens of $/ 1 /$. The interviews followed the guidelines prescribed by Labov (I984) for the elicitation of natural spontaneous discourse based on his work on sociolinguistic variation in the US. The conversational modules were the same across the interviews, and included both formal and informal topics such as visits to France, hobbies and pastimes, employment and university studies, as well as Labov's famous modules concerning 'danger of death', and 'premonitions'. Each interview lasted approximately one hour, and was conducted in a university office where the interviewer aimed at making the atmosphere as relaxed as possible. At the end of their interview, the informants completed a sociolinguistic questionnaire which further provided insight into their language learning background. Whilst the learners knew that their interviews were being recorded for the purposes of a research study, they were not aware of the nature of that research. All the informants participated voluntarily in the study. Following the interviews with the learners, the researchers adopted the transcription conventions proposed by Blanche-Benveniste and Jeanjean (1987) for target language French.

\section{Data analysis}

All tokens of / $/$ / were extracted from the data, and subsequently coded by the two first authors. Whilst $/ 1 /$ deletion is seen to occur in a range of contexts in native speaker French, the occurrence of some tokens where such variation occurred in the learner data was found to be too minor or non-existent for the results to be significant. For example, the learners were not found to vary in their realisation of $/ 1 /$ in word-initial position, namely in the definite articles 'le', 'la' and 'les', as well as in the pronouns 'le', 'la,' 'les', 'lui' and 'leur'. Similarly, the learners realised the $/ 1 /$ in a quasi-categorical manner in word-final and word-median position such as 'quelqu'un' and 'table'. The analysis is therefore restricted to the occurrence of the variable in third person subject pronouns, namely 'il' in both personal and impersonal contexts, 'elle', 'ils' and 'elles'. We excluded tokens of the variable which were immediately followed by a word beginning with $/ 1 /$ in view of the phonetic ambiguity arising. For the purpose of our analysis, we followed variationist methodological procedures developed by Labov, Poplack, Sankoff and others (see, for instance, Labov, I984; Poplack, I989; and Sankoff, I982). The data were coded for a range of factors predicted to constrain the learners' use of this variable. These factors are listed with examples in Table I, such as the individual speaker's gender, speech style, as well as other linguistic factors. In the coding of these factors, the researchers consulted with each other in the aim of inter-rater reliability. ${ }^{21}$ The factors are primarily adapted from Poplack and Walker's study of the native speaker, so as to allow a comparative investigation of how such factors might similarly constrain the L2 learner's use of this variable.

21 The rate of reliability was not quantitatively recorded. 
Table I. Factor groups

\begin{tabular}{ll}
\hline \hline & Example \\
\hline Following phonological segment & Il est retourné \\
Vowel & Elle parlait \\
Consonant & Ò̀ elle travaillait \\
Preceding phonological segment & Parce qu'il est revenu \\
Vowel & o elles sont arrivées \\
Consonant & Elles travaillaient \\
Pause & Il y est allé \\
Following grammatical category & Il ne comprend pas \\
Verb & \\
Pronoun & Il pleuvait \\
Other & Il sortait tout le temps \\
Pronoun & Elle va en France demain \\
Il (impersonal) & Ils sont partis le trois juin \\
Il (personal) & Elles pensent étudier l'anglais \\
Elle & \\
Ils & Il s'agit d'une difficulté énorme \\
Elles & Il est intéressant, ce prof \\
Position and distance of co-referent & Ce mec, il est chouette \\
No co-referent & Il est mal à l'aise, quand on pose des \\
Following & questions, cet homme \\
Preceding & L'enfant, quand nous sommes sortis, elle \\
I clause, right & a pleuré \\
& Mes amis qui étaient à Paris ont décidé de \\
I clause left & revenir ils sont retournés le 4 août \\
& \\
2 or more clauses away, right or left & \\
Unknown & \\
Speaker's gender & \\
Male & \\
Female & \\
Style & \\
Formal & \\
Informal & \\
\hline \hline &
\end{tabular}

With a view to obtaining frequency counts and factor weightings concerning the significance of such factors on the learners' use of either variant, the data were analysed using GoldVarb 200I, a logistic regression factor-analysis program. The program performs a step-wise regression analysis presenting an ordered selection of the factors. Factors whose effect is shown to be greater than a value of 0.5 are considered to favour use of a particular variant, whilst a value of less than 0.5 suggests that use of that variant is disfavoured.

\section{RESULTS}

Those speakers who never went to France were shown to delete the /1/ at a rate of 6 per cent. In contrast, the rate of /1/ deletion for those who had spent a year 


\section{L2 acquisition of a phonological variable}

in France was 33 per cent, which was a considerable increase. Clearly, contact with native speakers during a stay in the speech community had a marked effect on /1/ deletion in our L2 speakers of French. However, this rate is nonetheless considerably inferior to those rates observed in the case of the native speaker. As previously noted above, near-categorical levels of deletion are observed in the native speaker's use of these pronouns, particularly in the case of the use of 'il'. Native speaker rates range from 88 per cent (Ashby, I984) to near-categorical levels (Armstrong, I996) in continental French speech, which is taken to be the input available to the L2 speakers of the study.

It remains to be seen how these L2 speakers might vary their level of deletion across individual pronouns, and also as a function of the various other factors predicted to constrain their deletion. Table 2 presents the results for all factor groups, with the exception of gender, style and the position and distance of the co-referent, which were not found to be significant. It is noteworthy that, with regard to the two latter factors, similar findings have been reported by Poplack and Walker (I986) in the case of the native speaker. Since /1/ deletion was found to be minimal amongst the classroom learners who had not been to France, such that there are very clear differences between these L2 speakers and those who had been abroad, the results presented concern the latter group of speakers only.

The results clearly indicate that $/ 1 /$ deletion is not a uniform phenomenon in learner language, but rather a number of contextual factors promote deletion to a greater extent than others. With regard to the individual pronoun concerned, we note that impersonal 'il' favours deletion $(. p=.632)$, as do the plural pronouns 'ils' and 'elles' $(. p=.520)$, unlike the other pronoun types which favour $/ 1 /$ realisation (respective .p values for 'il' and 'elle' are .353 and .I5I). On this score, our results are in line with findings for the continental native speaker, for whom Armstrong (I996, 200I) and Ashby (I984) report a similar effect. That is to say, the distinction that our learners make in their level of deletion with impersonal and personal 'il', as well as with the other pronouns is exactly in line with the pattern of use observed in the case of the native speaker. ${ }^{22}$ Just as in the case of the native speaker, the higher rate of $/ 1 /$ deletion with impersonal 'il' reflects the learners' tendency to use this variable in lexicalised chunks, such as 'il y a' and 'il faut', where 'il' carries an impersonal value. In contrast, the L2 speakers demonstrate a lower /1/ deletion rate in contexts where the pronoun assumes a personal value, reflecting a similar tendency among native speakers. Given that there were only five tokens of 'elles', we decided to collapse this pronoun with 'ils'. ${ }^{23}$ Armstrong observes nearcategorical deletion among his native speaker informants in the case of 'ils', which

${ }^{22}$ In contrast, in the case of Canadian French speakers, Poplack and Walker (I986) report categorical levels of deletion in both personal and impersonal 'il', such that no effect is noted for the effect of the personal or impersonal value that this pronoun may assume.

23 The infrequent occurrence of 'elles' has been observed in other studies. In addition, our speakers failed at times to distinguish between masculine and feminine plural 'ils'/'elles', by overusing 'ils' in contexts where 'elles' might be prescribed. Armstrong (I996) reports a similar tendency amongst his native speaker informants. 


\section{L2 acquisition of a phonological variable}

With regard to comparisons with findings concerning other L2 studies, our findings show a considerable difference with those presented by Thomas (2002) in a Canadian context. His findings suggest little difference in levels of deletion by his L2 informants between personal 'il', impersonal 'il', and 'ils', a finding which reflects that observed by Poplack and Walker for their native speaker informants. Such important differences in findings between our study and that of Thomas point to the important effect that the learners' native speaker 'norm' may exert on their acquisition. $^{25}$

Apart from the factor of the actual pronoun concerned, a further similarity between this L2 study and the native speaker studies is observed for the factor of the following phonological segment. The common tendency for consonants as opposed to vowels to favour deletion across the native speaker studies is reflected in our learners' pattern of deletion. The .p values are .546 for consonants as opposed to .459 for vowels.

With regard to the other factor groups found to be significant, it is, however, more difficult to make a comparison with other native speaker studies since they do not systematically investigate such factors. Thus, in the case of the factor of the following grammatical category, pronouns were found to favour deletion (.p value $=.639)$, as were other grammatical categories such as the negative particle 'ne' (.p value $=.5$ I 3$)$. This is in contrast with verbs $(. p$ value $=.405)$ which are found to disfavour deletion. The preceding phonological segment was also found to exert an influence, with vowels and pauses favouring deletion, unlike in the case of consonants.

While we also considered stylistic and sociobiographic factors, neither gender nor style were shown to be significant. This is unlike some L2 studies which have reported an effect for both factors in the case of a number of other variables, such as Adamson and Regan (I99I), Blondeau et al. (2002), Major (2004), Mougeon and Rehner (200I), Nadasdi et al. (200I) and Rehner et al. (2003). While Major suggests that gender differences are acquired before stylistic differences, our findings suggest that our informants have yet to acquire such patterns of deletion, as observed in the case of the native speaker studies of /1/ deletion. For example, Armstrong (I996, 200I) observes a general rate of deletion of 35.2 per cent amongst his adolescent male informants aged I6-I9, as opposed to a rate of 54.2 per cent amongst their female counterparts in the same age group. ${ }^{26}$ While Major's hypothesis concerning the late emergence of stylistic differences relative to gender differences is confirmed in his study of a range of variables in L2 English, it is noteworthy that his informants had somewhat longer L2 exposure in the target language community compared to our informants. It seems therefore that some further development remains to be

potentially impact on the low level of deletion in 'elle', it must also be acknowledged that the speakers are reflecting the similar tendency observed in the native speaker.

25 For discussion of this issue, see Mougeon and Young (I996).

${ }^{26}$ In contrast, the informants in the much earlier Canadian study described by Poplack and Walker were found to demonstrate the opposing gender pattern. 
made by our informants before such gender differences are seen to underlie their use of the variable in hand.

In the case of style, the failure to find a significant effect is in line with that observed by some previous studies of L2 speech which have investigated stylistic factors, such as Mougeon et al. (200I) in the case of /1/ deletion and Rehner and Mougeon (I999) in the case of 'ne' deletion. ${ }^{27}$ A number of explanations can be proposed as to why that should be the case. Firstly, it should be noted that, in the case of the specific variable investigated, some studies, such as Laks (I980), do not report an effect for style, while others, such as Armstrong (I996, 200I) report a minimal effect in the case of deletion in the context of impersonal 'il'. In this regard, our L2 speakers are not behaving in ways dissimilar to the native speaker. However, notwithstanding this argument, the fact remains that the L2 speakers in our study do not demonstrate the effect for style that has otherwise been reported as characterising the native speaker's use of the variable in other contexts. In this regard, Tyne (2004) offers an interesting interpretation, based on his study of the use of slang vocabulary by his British L2 speakers of French. While he does report an effect for style, he also notes that the L2 speaker overuses slang vocabulary in tandem with more formal linguistic features, giving rise to a curiously non-native effect. Tyne suggests that the speakers may be using every opportunity to demonstrate their use of such slang vocabulary, such that 'on constate que certains mots, certaines tournures, etc. deviennent des "formes fétiches", des "favoris" (Tyne, 2004: 46). However, unbeknown to the L2 speaker, they are contradicting their intention 'de faire natif' (Dewaele and Regan, 2002: I3 I), insofar as their overuse of such vocabulary is at odds with the native speaker's more judicious use of such vocabulary in appropriate stylistic contexts.

In the same way, our L2 speakers' overuse of the informal variant within a formal style reflects an attempt to 'faire natif', which involves, however, incongruence of their relative overuse of this informal variant during a formal style. That overuse is evident insofar as the learners do not distinguish their use of the variant across styles. Such overuse of a phonological variant suggests that Tyne's observation concerning the co-occurrence of slang vocabulary with other more formal features, is not restricted to lexis alone, but rather extends to other levels of language. In the case of $/ 1 /$ deletion amongst our informants, it would therefore seem that their sociolinguistic competence needs refining to more closely approach native speaker stylistic norms.

Apart from the linguistic, social and stylistic factors so far discussed, it must also be noted that considerable individual variation characterises the speakers' use of the variable. That is to say, the level of deletion across the speakers is by no means a uniform phenomenon, but rather some learners delete considerably more than others. This is not a surprising finding, but rather reflects that observed not only

${ }^{27}$ In contrast, Regan (I996), Tyne (2004) and Uritescu et al. (2004) do find an effect for style in the case of their respective studies of 'ne' deletion, use of slang vocabulary, and schwa deletion. 


\section{L2 acquisition of a phonological variable}

in previous studies of the L2 acquisition of sociolinguistic variation, such as Regan (I995), but also in study abroad research (for an overview, see Collentine and Freed, 2004; and Howard, 2005d). While beyond the scope of this article, such individual variation in a study abroad context can be hypothesized to reflect the effect of various extra linguistic factors which impact on the speaker's L2 development, such as, amongst others, the extent of the speaker's interaction in the L2, the speaker's integration in the L2 community, and the speaker's residence and raison d'être whilst abroad.

\section{DISCUSSION}

The general conclusions of this study of /1/ deletion by L2 speakers of French are:

- instructed L2 speakers almost never delete /1/ prior to a prolonged stay in the native speech community;

- the speakers delete considerably more after a year in France but still much less than native speakers;

- there is variability in the deletion of /1/ in the speech of $\mathrm{L}_{2}$ speakers even in pre-consonantal position where native speaker deletion is virtually categorical;

- although the rates of deletion are considerably less than those of native speakers, the effects of those factors found to be significant in both this study and in the native speaker studies emerge as similar in relation to the constraint hierarchies observed.

We compared our results where possible with results from some other studies of both native speakers and non-native speakers. The conclusions drawn are general, as all of the studies are conducted in slightly different conditions. However, some interesting differences and similarities emerge. Table 3 presents the rates of deletion observed across studies of the native speaker and L2 speaker in different learning contexts.

\section{/l/ deletion amongst native speakers}

While we do not have a control group of native speakers in this particular study, we compared our speakers with the native speakers from several other studies of /1/ deletion in native speech in both Canadian French and continental French, namely Armstrong (1996), Ashby (I984), Laks (I980), Poplack and Walker (I986) and Sankoff and Cedergren (I976). Poplack and Walker report rates from Ottawa-Hull. They find that $/ 1 /$ is categorically deleted in the case of 'il' and 'ils'. The feminine subject pronoun, 'elle' shows rates reaching 84 per cent, whilst 'elles' has a rate of deletion of 33 per cent. Based on a study in Montréal, Sankoff and Cedergren find similar levels of deletion: ranging from 98 per cent for impersonal 'il' to 63 per cent for 'elle'. Levels of deletion are found to be lower in continental French. For example, Armstrong (I996), Ashby (I984) and Laks (I980) find that speakers delete 
Table 3. Rates of $/ l /$ deletion in native and non-native French speakers

\begin{tabular}{ll}
\hline \hline $\begin{array}{l}\text { Native speakers in Canada (Poplack and Walker, I986), } \\
\text { (Sankoff and Cedergren, I976) }\end{array}$ & 82 per cent (Ottawa-Hull) \\
Native speakers in France (Ashby, I984), & 6 I per cent (Tours) \\
(Laks, I980), & 59 per cent (Paris) \\
$\quad$ (Armstrong, I996) & 32 per cent (Dieuze) \\
$\begin{array}{l}\text { Non-native Irish speakers after one year abroad } \\
\text { (this study) }\end{array}$ & 33 per cent \\
$\begin{array}{l}\text { Non-native American speakers after 2-5 months abroad } \\
\text { (Sax, 2000) }\end{array}$ & 24 per cent \\
$\begin{array}{l}\text { Non-native Irish speakers prior to time abroad } \\
\text { (this study) }\end{array}$ & 6 per cent \\
$\begin{array}{l}\text { Non-native American speakers with little or no time } \\
\text { abroad (Sax, 20oo) }\end{array}$ & 4 per cent \\
$\begin{array}{l}\text { Non-native Canadian learners in the immersion } \\
\text { classroom (Mougeon } \text { et al., 200I) }\end{array}$ & 2 per cent \\
\hline \hline
\end{tabular}

slightly less than Canadian speakers with overall rates of 32 per cent, ${ }^{29} 62$ per cent, and 59 per cent respectively. Their studies are based on native speakers in Eastern France, Tours and Paris. However, similar to the Canadian findings, the most recent of these studies reports near-categorical levels of deletion for impersonal 'il', slightly higher than that found by Ashby (88 per cent) and Laks (94 per cent), which may suggest an evolution in $/ 1 /$ deletion in contemporary French.

\section{/l/ deletion amongst L2 speakers}

Canadian immersion L2 speakers

Mougeon et al. (200I) studied /1/ deletion by classroom immersion learners in Ontario. They found that overall these speakers deleted less than 2 per cent of the time. The context most favourable to deletion is the expression 'il y a' (a phonetically natural context for $/ 1 /$ deletion since $/ 1 /$ is followed by yod). 'Elle' is completely impervious to deletion. Also, these immersion learners delete more in the context of impersonal 'il' than plural 'ils' or singular personal 'il'. While the immersion students' rates are low, the constraint ordering in this regard is similar to that of Li speech. Our findings are similar. On the whole, however, the immersion speakers delete very infrequently.

\section{American year abroad L2 speakers}

Sax (2000) investigated /1/ deletion by American L2 speakers. Time spent abroad in Sax's study emerged as the strongest predictor of $/ 1 /$ deletion. Learners who had spent either no time or up to two weeks abroad were strongly disfavoured to delete

28 Armstrong only includes tokens of personal 'il' and 'elle', since deletion was observed to be categorical in the case of impersonal 'il' and 'ils'. Tokens of 'elles' were too infrequent to be included in his analysis.

29 Based on deletion in personal 'il' and 'elle' only. 


\section{L2 acquisition of a phonological variable}

/1/ (VARBRUL rate of .I4), as were learners with between two and five months abroad (VARBRUL rate of .36). The American learners with between eight months and four years abroad were strongly favoured to delete /1/ (VARBRUL rate of .78).

\section{Irish instructed and year abroad L2 speakers}

Our findings in relation to $/ 1 /$ deletion in Hiberno-English speakers of French show distinct similarities to the findings of Sax in relation to her American speakers. In both cases, the speakers deleted virtually not at all before a prolonged stay in France, similar to the Canadian classroom immersion speakers. However, they deleted considerably more after several months in France, 33 per cent for the Irish speakers spending a year in France, and 24 per cent for the Americans who spent between two and five months there. Similar to the native speaker, our Irish L2 speakers also delete $/ 1 /$ most frequently in the case of impersonal 'il', at a rate of 45 per cent which is nonetheless considerably lower than the near-categorical levels attained by the native speaker.

While such differences relate to levels of deletion, we nonetheless note that the learners demonstrate the same constraint ordering as that observed for those linguistic factors investigated in the native speaker studies. Apart from the factors of the preceding phonological segment and the following grammatical segment investigated here, the other factors concerning the type of pronoun and the following phonological segment have also been found to be significant in the native speaker studies. Similar factors are also found in the American year abroad students and in the Canadian classroom immersion students, although at very different rates. Nonetheless, with regard to the factors of gender and style, it remains for the learners to acquire such native-like patterns of variation.

\section{CONCLUSION}

This study on the variation patterns in the speech of L2 learners of French further supports the suggestion made by previous research outlined above that $\mathrm{L} 2$ speakers can in some way approximate Li variation norms. This study of / / deletion adds to the picture which is being gradually built up of the acquisition of native speech patterns in sociolinguistic competence.

The study seems to provide further evidence that certain areas of the grammar of a language are sensitive to certain types of input. Collentine and Freed (2004) caution against an overly positive view of Study Abroad in relation to other areas of the instructed learner's L2 acquisition, but in relation to sociolinguistic competence at least, it seems to be strongly indicated that this particular context is crucial. As regards Study Abroad as a context for acquiring an L2, this study adds to the evidence already in existence that the acquisition of sociolinguistic competence, in particular, seems to respond to living in the native speech community.

Interestingly, in her study of /1/ deletion by American L2 speakers, Sax (200I) finds that more years of classroom instruction resulted in less deletion. We are now increasingly sure that the acquisition of native speech variation patterns is by 
no means fully successful in a 'traditional' classroom, as it is currently. It looks as if, for /1/ deletion as with previous variables studied, living in the native speech community does what the classroom cannot do for the acquisition of native speaker variation patterns.

Address for correspondence:

Martin Howard

Department of French

University College, Cork

Cork

Ireland

e-mail:mhoward@french.ucc.ie

\section{REFERENCES}

Adamson, H. D. and Regan, V. (I99I). The acquisition of community speech norms by Asian immigrants learning English as a second language. Studies in Second Language Acquisition, I3: I-22.

Armstrong, N. (1996). Variable deletion of French /1/: linguistic, social and stylistic factors. Journal of French Language Studies, 6: I-22.

Armstrong, N. (200I). Social and Stylistic Variation in Spoken French: A Comparative Approach. Amsterdam/Philadelphia: Benjamins.

Ashby, W. (1984). The elision of $/ 1 /$ in French clitic pronouns and articles. In: E. Pulgram (ed.), Romanitas: Studies in Romance Linguistics. Ann Arbor: University of Michigan Press, pp. I-I6.

Bayley, R. (I996). Competing constraints on variation in the speech of adult Chinese learners of English. In: R. Bayley and D. Preston (eds), Second Language Acquisition and Linguistic Variation. Amsterdam/Philadelphia: Benjamins, pp. 97-I20.

Bayley, R. and Regan, V. (eds) (2004). Sociolinguistics and Second Language Acquisition. Special issue of Journal of Sociolinguistics, 8.3.

Bayley, R. and Preston, D. (1996). Second Language Acquisition and Linguistic Variation. Amsterdam/Philadelphia: Benjamins.

Blanche-Benveniste, C. and Jeanjean, C. (1987). Le français parlé : transcription et édition. Paris: Didier Erudition.

Blondeau, H., Nagy, N., Sankoff, G. and Thibault, P. (2002). La couleur locale du français L2 des Anglo-montréalais. In: J.-M. Dewaele and R. Mougeon (eds), L'appropriation de la variation par les apprenants du français langue seconde. Special issue of Acquisition et Interaction en Langue Étrangère, I7: 73-100.

Collentine, J. and Freed, B. (eds)(2004). Learning Context and its Effects on Second Language Acquisition. Special issue of Studies in Second Language Acquisition, 26.

Dewaele, J.-M. (I992). L'omission du 'ne' dans deux styles oraux d'interlangue française. Interface Journal of Applied Linguistics, 7: 3-I7.

Dewaele, J.-M. (I995). Variation critique dans l'interlangue: une analyse critique du modèle du Caméléon de E Tarone. ITL Review of Applied Linguistics, I09/ I I0: I-I 8.

Dewaele, J.-M. (2002a). Using socio-stylistic variants in advanced French interlanguage: the case of 'nous'/'on'. Eurosla Yearbook, 2: 205-226. 


\section{L2 acquisition of a phonological variable}

Dewaele, J.-M. (2002b). Variation, chaos et système en interlangue française. In: J.-M. Dewaele and R. Mougeon (eds), L'appropriation de la variation par les apprenants $d u$ français langue seconde. Special issue of Acquisition et Interaction en Langue Etrangère, I 7: I $43-167$.

Dewaele, J.-M. (2004a). Retention or omission of the 'ne' in advanced French interlanguage: the variable effect of extralinguistic factors. In: R. Bayley and V. Regan (eds), Sociolinguistics and Second Language Acquisition. Special issue of Journal of Sociolinguistics, 8: 433-450.

Dewaele, J.-M. (2004b). 'Vous' or 'tu'? Native and non-native speakers of French on a sociolinguistic tightrope. In: J.-M. Dewaele and R. Mougeon (eds), Variation in the Interlanguage of Advanced Second Language Learners. Special issue of International Review of Applied Linguistics, 42.4: 383-402.

Dewaele, J.-M. (2004c). Individual differences in the use of colloquial vocabulary: the effects of sociobiographical and psychological factors. In: P. Bogaards and B. Laufer (eds), Learning Vocabulary in a Second Language: Selection, Acquisition and Testing. Amsterdam/Philadelphia: Benjamins, pp. I27-I 53 .

Dewaele, J.-M. and Mougeon, R. (eds) (2002). L'appropriation de la variation par les apprenants du français langue seconde. Special issue of Acquisition et Interaction en Langue Etrangère, I 7.

Dewaele, J.-M. and Mougeon, R. (eds) (2004). Variation in the Interlanguage of Advanced Second Language Learners. Special issue of International Review of Applied Linguistics, 42.4 .

Dewaele, J.-M. and Regan, V. (200I). The use of colloquial words in advanced French interlanguage. Eurosla Yearbook, I: 205-226.

Dewaele, J.-M. and Regan, V. (2002). Maîtriser la norme sociolinguistique en interlangue française: le cas de l'omission variable de 'ne'. Journal of French Language Studies, I2: I23-I 48 .

Dewaele, J.-M. and Véronique, D. (200I). Gender assignment and gender agreement in advanced French interlanguage: A cross-sectional study. Bilingualism: Language and Cognition, 4.3: 275-297.

Eckert, P. and Rickford, J. (eds) (200I). Style and Sociolinguistic Variation. New York: Cambridge University Press.

Ervin-Tripp, S. (1972). On sociolinguistic rules: Alternation and co-occurrence. In: J. Gumperz and D. Hymes (eds), Directions in Sociolinguistics: The Ethnography of Communication. New York: Holt, Rinehart and Winston, pp. 2 I 3-250.

Gass, S., Madden, C., Preston, D. and Selinker, L. (eds) (1989). Variation in Second Language Acquisition. Psycholinguistic Issues. Clevedon: Multilingual Matters.

Howard, M. (2002). Les interrelations entre les facteurs contraignant l'emploi variable des temps du passé. Revue Française de Linguistique Appliquée, VII, I: 3 I-42.

Howard, M. (2004). Sociolinguistic variation and second language acquisition: A preliminary study of advanced learners of French. SKY Journal of Linguistics, I7: I $43-165$.

Howard, M. (2005a). L'acquisition de la liaison en français langue seconde. Une analyse quantitative d'apprenants avancés en milieu guidé et en milieu naturel. Cognition, Représentation, Langage (Revue CORELA), III, I.

Howard, M. (2005b). Les emplois marqués et prototypiques de l'imparfait par l'apprenant du français langue étrangère. In: E. Labeau and P. Larrivée (eds), Nouveaux 
développements de l'imparfait. Amsterdam/Atlanta, Rodopi [Cahiers Chronos I4], pp. I75-I97.

Howard, M. (2005c). The emergence and use of the 'plus-que-parfait' in advanced French interlanguage. In: J.-M. Dewaele (ed.), Focus on French as a Foreign Language: Multidisciplinary Perspectives. Clevedon, Multilingual Matters [Second Language Acquisition Io], pp. 63-87.

Howard, M. (2005d). On the role of context in the development of learner language: Insights from study abroad research. ITL Journal of Applied Linguistics, I47/48: I-20.

Labov, W. (1984). Field methods of the project on language change and variation. In: J. Baugh and W. Scherzer (eds), Language in Use: Readings in Sociolinguistics. Englewood Cliffs, NJ: Prentice Hall, pp. 28-53.

Labov, W. (1994). Principles of Language Change. Vol I Internal Factors. Oxford: Blackwell. Labov, W. (200I). Principles of Language Change. Vol 2 Social Factors. Oxford: Blackwell.

Laks, B. (1980). Différenciation linguistique et différenciation sociale: quelques problèmes de linguistique française. Doctoral Thesis, Université de Paris VIII-Vincennes.

Lemée, I. (2002). Acquisition de la variation socio-stylistique dans l'interlangue d'apprenants hibernophones de français: le cas de on et nous. Marges Linguistiques, 4: 56-67.

Lyster, R. (1994). The effect of functional-analytic teaching on aspects of French immersion students' sociolinguistic competence. Applied Linguistics, I 5: 263-287.

Lyster, R. and Rebuffot, J. (2002). Acquisition des pronoms d'allocution en classe de français immersif. In: J.-M. Dewaele and R. Mougeon (eds), L'appropriation de la variation par les apprenants du français langue seconde. Special issue of Acquisition et Interaction en Langue Etrangère, I 7: 5 I-72.

Major, R. (2004). Gender and stylistic variation in second language phonology. Language Variation and Change, I6.3: I64-188.

Mougeon, F. and Young, L. (I996). Quel français parler? Initiation au français parlé au Canada et en France. Canadian Modern Language Review, 52, 4.

Mougeon, R., Nadasdi, T. and Rehner, K. (2002). Etat de la recherche sur l'appropriation de la variation par les apprenants avancés du FL2 ou FLE. In: J.-M. Dewaele and $\mathrm{R}$. Mougeon (eds), L'appropriation de la variation par les apprenants du français langue seconde. Special issue of Acquisition et Interaction en Langue Etrangère, I 7: 7-30.

Mougeon, R., Nadasdi, T., Uritescu, D. and Rehner, K. (200I). A sociolinguistic analysis of phonetic variation in the spoken French of immersion students. Paper presented at the annual conference of the Canadian Association for Applied Linguistics, Québec City.

Mougeon, R. and Rehner, K. (200I). Variation in the spoken French of Ontario French immersion students: the case of juste v. seulement v. rien que. Modern Language Journal, 85:398-4I4.

Nadasdi, T. (200I). Agreeing to disagree: variable subject-verb agreement in immersion French. Canadian Journal of Applied Linguistics, 4: 79-Іог.

Nadasdi, T. and McKinnie, M. (2003). Living and working in immersion French. Journal of French Language Studies, I3.I: 47-6I.

Nadasdi, T., Mougeon, R. and Rehner, K. (2003). Emploi du futur dans le français parlé des élèves d'immersion française. Journal of French Language Studies, I 3: I95-220.

Nagy, N., Moisset, C. and Sankoff, G. (I996). On the acquisition of variable phonology in L2. Penn Working Papers in Linguistics, 3: I I I-I26. 


\section{L2 acquisition of a phonological variable}

Nagy, N., Blondeau, H. and Auger, J. (2004). Second language acquisition and 'real' French: An investigation of subject doubling in the French of Montreal Anglophones. Language Variation and Change, I 5: 73-103.

Olson-Flanagan, B. and Inal, E. (I996). Object relative pronoun use in native and nonnative English: A variable rule analysis. Language Variation and Change, 8: 203-226.

Poplack, S. (1989). The care and handling of a megacorpus: The Ottawa-Hull French project. In R. Fasold and D. Schiffrin (eds), Language Change and Variation, Amsterdam/Philadelphia: Benjamins, pp. 4I I-45I.

Poplack, S. and Walker, D. (I986). Going through /1/ in Canadian French. In D. Sankoff (ed.), Diversity and Diachrony. Amsterdam/Philadelphia: Benjamins, pp. I73-I98.

Preston, D. (1989). Sociolinguistics and Second Language Acquisition. Oxford: Blackwell.

Preston, D. (I996). Variationist perspectives on second language acquisition. In R. Bayley and D. Preston (eds), Second Language Acquisition and Linguistic Variation. Amsterdam/Philadelphia: Benjamins, pp. I-45.

Regan, V. (I995). The acquisition of sociolinguistic native speech norms: Effects of a year abroad on the L2 learners of French. In: B. Freed (ed.), Second Language Acquisition in a Study Abroad Context. Amsterdam/Philadelphia: Benjamins, pp. 245-267.

Regan, V. (1996). Variation in French interlanguage: a longitudinal study of sociolinguistic competence. In: R. Bayley and D. Preston (eds), Second Language Acquisition and Linguistic Variation. Amsterdam/Philadelphia: Benjamins, pp. I77-20I.

Regan, V. (2004). From speech community back to classroom: What variation analysis can tell us about the role of context in the acquisition of French as a foreign language. In: J.-M. Dewaele (ed.), Focus on French as a Foreign Language. Multidisciplinary Perspectives. Clevedon: Multilingual Matters, pp. I9I-209.

Regan, V., Howard, M. and Lemée, I. (to appear). The Acquisition of Sociolinguistic Competence in a Study Abroad Context. Clevedon: Multilingual Matters [Second Language Acquisition Series].

Rehner, K. (2004). Developing Aspects of Second Language Discourse Competence. Munich: Lincom.

Rehner, K. and Mougeon, R. (1999). Variation in the spoken French of immersion students: to 'ne' or not to 'ne', that is the sociolinguistic question. Canadian Modern Language Review, 56: I24-I 54.

Rehner, K., Mougeon, R. and Nadasdi, T. (2003). The learning of sociolinguistic variation by advanced FSL learners. The case of 'nous' versus 'on' in immersion French. Studies in Second Language Acquisition, 25: 127-I 56.

Roberts, J. (1994). Acquisition of Variable Rules: $t / d$ Deletion and 'ing' Production in Pre-School Children. Unpublished PhD Dissertation, University of Pennsylvania, Philadelphia.

Sankoff, D. (1982). Sociolinguistic method and linguistic theory. In: L. Cohen (ed.), Logic, Method, Philosophy of Science, Vol VI. Amsterdam: North Holland, pp. 677-689.

Sankoff, G. and Cedergren, H. (I976). Les contraintes linguistiques et sociales de l'élision de /1/ chez les Montréalais. In: M. Boudreault and F. Mohren (eds), Actes du XIIIème congrès international de linguistique et philologie romanes. Québec: Presses de l'Université Laval, pp. i Iог-i I 7 .

Sax, K. (2000). Acquisition of stylistic variation by American learners of French: /1/ elision in the subject pronouns 'il' and 'ils'. Paper presented at the Second Language Research Forum 2000, Indiana University. 


\section{Martin Howard et al.}

Thomas, A. (2002). La variation phonétique en français langue seconde au niveau universitaire avancé. In: J.-M. Dewaele and R. Mougeon (eds), L'appropriation de la variation par les apprenants du français langue seconde. Special issue of Acquisition et Interaction en Langue Etrangère, I7: IOI-I2 I.

Towell, R. and Hawkins, R. (I994). Approaches to Second Language Acquisition. Clevedon: Multilingual Matters.

Trudgill, P. and Cheshire, J. (eds) (1998). The Sociolinguistic Reader. Vols. I and II. Clevedon: Multilingual Matters.

Tyne, H. (2004). Le style en français langue seconde: vers un regard sociolinguistique. In: F. Gadet (ed.), Le style comme perspective sur la dynamique des langues. Special issue of Langage et Société, I09: 3 I-5I.

Uritescu, D., Mougeon, R., Nadasdi, T. and Rehner, K. (2004). Acquisition of the internal and external constraints of variable schwa deletion by French immersion students. In: J.-M. Dewaele and R. Mougeon (eds), Variation in the Interlanguage of Advanced Second Language Learners. Special issue of International Review of Applied Linguistics, 42.4: 349-364.

Young, R. (I99I). Variation in Interlanguage Morphology. Frankfurt: Peter Lang.

Young, R. (I999). Sociolinguistic approaches to SLA. Annual Review of Applied Linguistics, I9: IO5-I32. 